\title{
Seasonal changes in feeding rate, digestive enzyme activity, and assimilation efficiency of Calanus pacificus
}

\author{
R. Patrick Hassett ${ }^{1}$, Michael R. Landry ${ }^{2}$ \\ ${ }^{1}$ Marine Sciences Research Center, State University of New York, Stony Brook, New York 11794, USA \\ ${ }^{2}$ Department of Oceanography and Hawaii Institute of Geophysics, University of Hawaii, 1000 Pope Rd., Honolulu, \\ Hawaii 96822, USA
}

\begin{abstract}
The feeding behavior of the marine calanoid copepod Calanus pacificus was investigated during the winter/spring transition in Puget Sound, Washington, USA. Maximum ingestion rate $\left(\mathrm{I}_{\max }\right)_{1}$ maximum clearance rate $\left(F_{\text {max }}\right)$, and digestive enzyme activity were determined during spring and fall 1982, and the same measures plus assimilation efficiency were determined during spring 1984. Maximal feeding rates and digestive enzyme activity increased concurrently with the onset of the spring bloom in 1982. In 1984 feeding rates and digestive enzyme activity were already fully developed at the start of the sampling period, apparently due to an unusually early bloom in Puget Sound. Once developed, digestive enzyme activity remained high even during periods when maximal feeding rates were declining. Assimilation efficiencies also were found to be relatively constant during the 1984 sampling
\end{abstract}

\section{INTRODUCTION}

Maximum feeding rates of Calanus pacificus in Puget Sound, Washington USA, undergo a seasonal change that cannot be explained solely by changes in the size of the copepods (Runge 1980). Runge suggested that these changes may be the result of longterm acclimation of the copepods to food conditions with the regulation of digestive enzymes a possible mechanism of acclimation. Seasonal changes in digestive enzyme activity have been observed in heterogeneous zooplankton samples (Mayzaud \& Conover 1976. Mayzaud \& Poulet 1978) and in individual calanoid species (Hirche 1981, Tande \& Slagstad 1982). Mayzaud \& Conover (1976) found a positive correlation between digestive enzyme activity and several measures of food concentration (protein, carbohydrate, chlorophyll a). A similar observation was also made by Hirche (1981). Mayzaud \& Poulet (1978) hypothesized that acclimation of digestive enzymes could be necessary before the copepod could take advantage of the increased food supply.

Previously we demonstrated that long-term acclima-

- Contribution No. 717 from the Marine Sciences Research Center and No. 2247 from the Hawaii Institute of Geophysics tion (on the order of 1 to 2 wk) to food concentration in the laboratory could affect both feeding rates and digestive enzyme activities of Calanus pacificus (Hassett \& Landry 1983). Maximum feeding rates declined and digestive enzyme activities either remained constant or decreased (depending on the enzyme) when $C$. pacificus fed for prolonged periods at high food concentrations. As a result, digestive enzyme activities were positively correlated with maximum ingestion rate following acclimation to different food levels. A short period of starvation was sufficient to eliminate the effects of food-level acclimation on maximum ingestion rates, but not on enzyme activities. From these results we argued that digestive enzyme activity may be a more accurate measure of feeding potential as opposed to a measure of the true rate of in vivo feeding (Hassett \& Landry 1983; see also Head \& Conover 1983, with regard to enzymes as a measure of feeding potentiall.

In order to interpret seasonal changes in feeding rates in light of our results from laboratory acclimation experiments, we here combine field measures of feeding rate with concurrent estimates of digestive enzyme activities and assimilation efficiencies. The present study describes the seasonal changes in the feeding responses of Calanus pacificus through the spring bloom and early fall period in the main basin of Puget 
Sound. Measurements were made of maximum ingestion and clearance rates (measured at high and low food concentrations respectively), dry weight, water temperature, chlorophyll a concentration, and 3 digestive enzymes (laminarinase, cellobiase, and maltase) which varied markedly in the seasonal study of Mayzaud \& Conover (1976).

\section{MATERIALS AND METHODS}

Field studies were conducted with adult female Calanus pacificus during the spring and early fall of 1982 and 1984. The 1982 study involved six $1 \mathrm{~d}$ sampling cruises from the end of March to mid-June and 3 cruises from late September to mid-October. Copepods were collected from the main basin of Puget Sound with a $1 \mathrm{~m}$ diameter, $500 \mathrm{um}$ mesh net towed for $10 \mathrm{~min}$ at a depth of $200 \mathrm{~m}$. Copepods were returned to the laboratory within a few hours of capture for the feeding experiments. While in the field, water samples were taken at depths of 0,20 , and $40 \mathrm{~m}$ by water pump for analysis of chlorophyll a concentration (Lorenzen 1966). Temperature was taken only at the surface since temperature differences through the water column are usually less than $2^{\circ} \mathrm{C}$ (Collias et al. 1974).

Upon returning to the lab, samples of copepods were removed and frozen in liquid nitrogen for subsequent dry weight measurements and digestive enzyme analyses. The remaining copepods were then sorted into $12 \mathrm{l}$ jars of filtered seawater and left overnight at $12^{\circ} \mathrm{C}$. The following day the copepods were transfered to 12 capped $1 \mathrm{l}$ jars for the grazing experiment. Aliquots of exponentially growing cultures of the diatom. Thalassiosira weissflogii were added to each experimental and control jar. Six experimental, 3 initial and 3 control, jars were run at each 2 concentrations: 1500 cells $\mathrm{ml}^{-1}$ (to measure maximum clearance rate) and 6000 cells $\mathrm{ml}^{-1}$ (to measure maximum ingestion rate). Later references to low and high food concentrations distinguish between concentrations below and above the level at which ingestion rate is saturated (ca 4000 cells $\mathrm{ml}^{-1} T$. weissflogii). The experiments were run for 5 to $6 \mathrm{~h}$ on a rotating wheel $(1 \mathrm{rpm})$ in dim light. Grazing rates were determined according to the equations of Frost (1972), using particle counts measured with an Elzone 80 XY Particle Analysis System. At the conclusion of the experiment the remaining copepods were removed and assayed for digestive enzyme activity to test for short-term changes during the course of feeding. Activities of 3 digestive enzymes, laminarinase, cellobiase, and maltase, were measured using a 2 step fluorometric assay (Hassett \& Landry 1982).

The 1984 field study involved 5 sampling cruises between late March and the end of June and 2 cruises in September Copepods were collected and handled as in 1982. However, chlorophyll a was not measured, and during the first part of the study the activity of only one digestive enzyme, laminarinase, was assayed. Feeding experiments were conducted in nested 11 polyethylene containers with the bottom of the inner container (which contained the copepods) having a $500 \mu \mathrm{m}$ mesh nitex screen to allow for the easy separation of the fecal pellets from the copepods. Thalassiosira weissflogii was added at the start of the experiment and aliquots were removed to provide an initial particle count. An initial sample was taken for the carbon, nitrogen, and chlorophyll a content of the phytoplankton stock. At the end of the experiment the inner container with the copepods was removed, and a final particle count was taken.

Assimilation efficiencies were estimated from the amount of carbon or nitrogen ingested (cells ingested $x$ carbon or nitrogen content cell ${ }^{-1}$ ) minus that egested (quantitative recovery of fecal pellets). Fecal pellets were separated from the phytoplankton remaining in the containers by several concentrations and dilutions through $73 \mu \mathrm{m}$ Nitex mesh. The fecal pellet sample was examined for copepod eggs; due to the overnight starvation period that preceded feeding, eggs were rarely produced during the short feeding interval. Fecal pellets were then filtered, dried at $60^{\circ} \mathrm{C}$, and analyzed for carbon and nitrogen content on a Carlo Erba elemental analyzer. Standards were weighed on a Cahn model 20 electrobalance. Assimilation efficiency (AE) was determined from the equation $\mathrm{AE}$ (carbon) $=\{1$-(carbon in fecal pellets/carbon in food) $\times 100$. In these experiments the conditions (container size, number of copepods, and duration of experiment) were adjusted to yield similar amounts of total cells ingested per container regardless of food concentration. Thus, any problem with contamination, which would tend to decrease apparent efficiency, should affect both the high and low concentration conditions equally.

\section{RESULTS}

The main basin has a seasonal cycle of food availability that is marked by the onset of a spring bloom in midApril or later and frequent blooms thereafter throughout the spring and summer (illustrated in Fig. 1, from samples collected in 1979-1980). There were changes in all parameters measured during the course of the spring bloom in 1982 (Figs. 2 and 3). Surface temperature, not depicted in the figures, increased gradually from $9^{\circ} \mathrm{C}$ on March 29 to $11^{\circ} \mathrm{C}$ on May 17 Maximum clearance rate $\left(F_{\max }\right)$, maximum ingestion rate $\left(\mathrm{I}_{\max }\right)$, and all 3 digestive enzymes showed significant changes during the spring period from March 29 to 


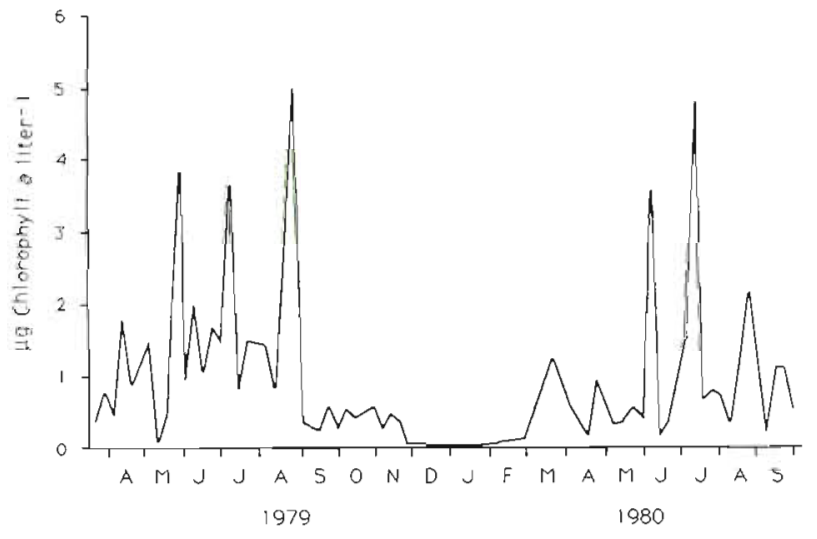

Fig. 1. Seasonal cycle of chlorophyll a (integrated from 0 to $35 \mathrm{~m}$ ) at Stn 1, Puget Sound, Washington, USA, during 1979 and 1980

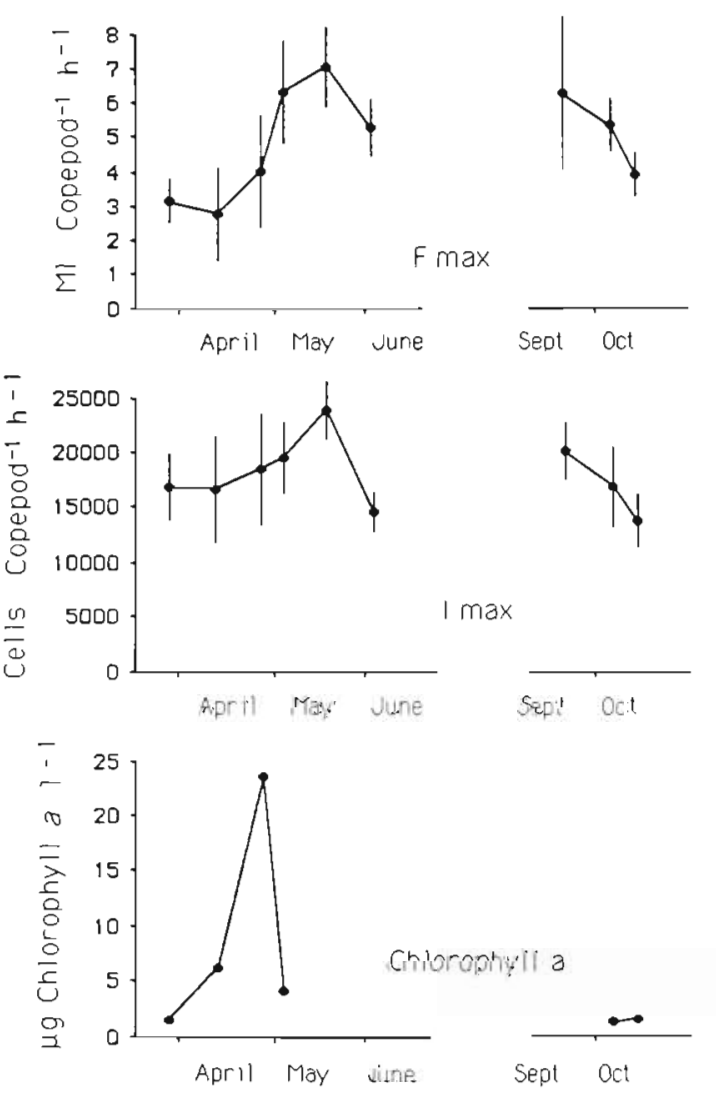

Fig. 2. Calanus pacificus. Seasonal changes in maximum clearance and ingestion rates, and chlorophyll a concentration in the main basin of Puget Sound during spring and autumn

1982. Values are means and $95 \%$ confidence intervals

June 3, 1982 (Table 1). An increase in copepod dry weight paralleled the seasonal increase in feeding rates. $I_{\max }$ increased at approximately the same rate as dry weight during the spring bloom, but later decreases in $I_{\text {max }}$ probably would not be explained by changes in dry weight. $F_{\max }$ increased disproportionately to dry weight, as previously described by Runge (1980).
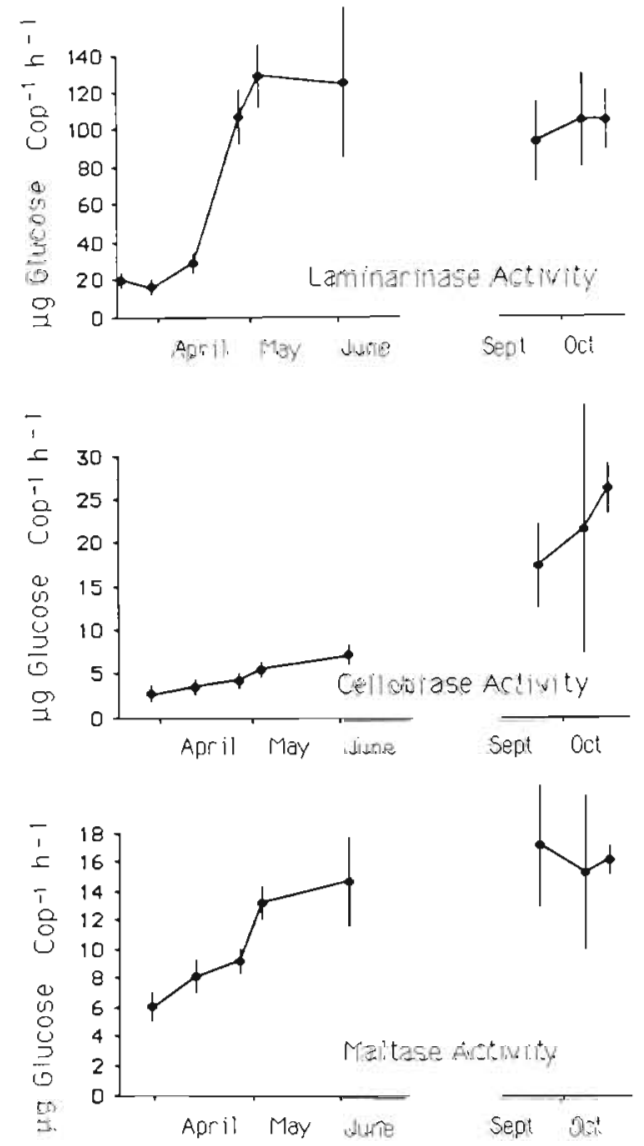

Fig. 3. Calanus pacificus. Seasonal changes in digestive enzyme activities in the main basin of Puget Sound, during spring and autumn 1982. Values are means and $95 \%$ confidence intervals

Table 1. Calanus pacificus. Changes in enzyme activities and feeding rates during the spring bloom period of 1982 (March 29 to June 3) in Puget Sound, Washington, USA. F max $_{\text {max- }}$ imum clearance rate; $\mathrm{I}_{\max }$ : maximum ingestion rate. Test of statistical significance based on Kruskal-Wallis test; $\mathrm{n}=$ number of observations

\begin{tabular}{|lll|}
\hline$F_{\max }$ & sig. $\mathrm{p}<0.005$ & $\mathrm{n}=33$ \\
$\mathrm{I}_{\max }$ & sig. $\mathrm{p}<0.01$ & $\mathrm{n}=33$ \\
Laminarinase activity & sig. $\mathrm{p}<0.005$ & $\mathrm{n}=80$ \\
Cellobiase acitivity & sig. $\mathrm{p}<0.005$ & $\mathrm{n}=80$ \\
Maltase activity & sig. $\mathrm{p}<0.005$ & $\mathrm{n}=80$ \\
\hline
\end{tabular}

Chlorophyll a concentration peaked in late April and subsequently showed a rapid decline. Although chlorophyll was not measured beyond the bloom, repeated blooms are to be expected throughout the summer (Fig. 1). Digestive enzyme activities increased during the bloom. The rise in laminarinase activity was particularly sharp. Increases in feeding rate appeared to be delayed by several weeks compared to digestive enzymes. There was also a sharp decrease in maximal feeding rates on the last sampling date of the spring, 
Table 2. Calanus pacificus. Correlation (Spearman rank test) between enzyme acitvities, feeding rates, and dry weight during spring 1982 (March 29 to May 3) I max: maximum ingestion rate; $F_{\max }$ : maximum clearance rate; $r$ : correlation coefficient; $n$ : number of observations. 'sig., $p<0.05,{ }^{\prime}$ sig. $p<0.01$

\begin{tabular}{|llr|}
\hline & $\mathrm{r}$ & $\mathrm{n}$ \\
\hline$I_{\max }-F_{\max }$ & $+0.74^{*}$ & 9 \\
$I_{\max }$-dry weight & +0.35 & 17 \\
$\mathrm{~F}_{\max }$-dry weight & $+0.50^{\circ}$ & 17 \\
$I_{\max }$-Laminarinase activity & +0.38 & 22 \\
$I_{\max }$-Cellobiase activity & +0.35 & 22 \\
$\mathrm{I}_{\max }$-Maltase activity & +0.39 & 22 \\
$\mathrm{~F}_{\max }$-Laminarinase activity & $+0.65^{\cdots}$ & 22 \\
$F_{\max }$-Cellobiase activity & $+0.65^{\cdots}$ & 22 \\
$\mathrm{~F}_{\max }$-Maltase activity & $+0.66^{\cdots}$ & 22 \\
\hline
\end{tabular}

June 3. Enzyme activities continued to increase (cellobiase and maltase) or remained the same (laminarinase) on this date. The 3 fall sampling dates, when chlorophyll values were low, initially showed a high maximum rate for both ingestion and clearance, followed by a decline. However, digestive enzyme activities remained high or increased (cellobiase), as feeding rates declined.

The similarity in the timing of the changes in the feeding rates and enzyme activities, not surprisingly, led to positive correlations among those parameters when measured over the course of the spring bloom. The strongest correlations were between maximum clearance rate and each of the 3 digestive enzymes (Table 2). However, when the data are compared on a specific date, that is, comparing feeding rates and enzyme activities within a single grazing experiment, the only consistently significant correlations are between individual digestive enzymes (Table 3 ). This lack of correlation between feeding rate and enzyme activity may be due to the smaller range of values on a given date relative to the range exhibited over the course of the bloom. Nonetheless, it does illustrate the problem of using digestive enzymes as indicators of grazing rates. This problem is further emphasized by the fall 1982 results where digestive enzyme activities remained high even while maximal feeding rates declined.

The data for 1984 provides an interesting contrast to 1982. Although sampling began several days earlier in 1984 (Mar 26 vs Mar 29) high laminarinase levels were already induced (Fig. 4). Maximal feeding rates were higher in 1984 than in 1982, but the trends over the course of spring were similar for both years (Fig. 5).

In the 1984 field season carbon and nitrogen assimilation efficiencies (AE) were determined for Calanus pacificus feeding on low (1300 cells $\left.\mathrm{ml}^{-1}\right)$ and high $(6000$ cells $\mathrm{ml}^{-1}$ ) concentrations of Thalassiosira weissflogii (Fig. 6). Food concentration had a significant effect on assimilation efficiency only for carbon AE on May 21 , with higher efficiencies at the higher food concentration $(p<0.05$, Wilcoxon 2 -sample test). The data from June 4 may have been affected by preconditioning of the copepods: this was the only experiment in which the copepods were starved for $3 \mathrm{~d}$ prior to the experiment. The copepods were starved for less than $2 \mathrm{~d}$ in other experiments. We have elsewhere indicated that the starvation period may influence initial assimilation of food (Hassett \& Landry 1988). There was little evidence for higher nitrogen assimilation efficiency as previously

Table 3. Calanus pacificus. Correlation (Spearman rank test) between enzyme acitvities, feeding rates, and dry weight for experiments conducted during given days in spring 1982. $\mathrm{I}_{\max }$ : maximum ingestion rate; $\mathrm{F}_{\max }$ : maximum clearance rate; $\mathrm{n}$ : number of observations. "sig., $p<0.1 ; \cdots$ sig., $p<0.05 ; \cdots$ sig., $p<0.01$

\begin{tabular}{|c|c|c|c|c|}
\hline & Mar 29 & Apr 12 & Apr 26 & May 3 \\
\hline $\begin{array}{l}\mathrm{I}_{\operatorname{mex}}-\text { Laminarinase } \\
\mathrm{I}_{\max }-\text { Cellobiase } \\
\mathrm{I}_{\max }-\text { Maltase } \\
\mathrm{n}\end{array}$ & $\begin{array}{l}+0.20 \\
-0.30 \\
-0.30 \\
5\end{array}$ & $\begin{array}{l}+0.81 \\
+0.53 \\
+0.19 \\
\quad 6\end{array}$ & $\begin{array}{l}+0.42 \\
-0.38 \\
+0.82 \\
5\end{array}$ & $\begin{array}{l}+0.03 \\
+0.47 \\
+0.71 \\
6\end{array}$ \\
\hline $\begin{array}{l}\mathrm{F}_{\max } \text {-Laminarinase } \\
\mathrm{F}_{\max } \text {-Cellobiase } \\
\mathrm{F}_{\operatorname{mix}}-\text { Maltase } \\
\mathrm{n}\end{array}$ & $\begin{array}{l}+0.57 \\
+0.57 \\
+0.70 \\
5\end{array}$ & $\begin{array}{l}-0.64 \\
+0.19 \\
-0.77 \\
6\end{array}$ & $\begin{array}{l}-0.30 \\
-0.12 \\
+0.32 \\
5\end{array}$ & $\begin{array}{l}+0.10 \\
-0.31 \\
-0.01 \\
6\end{array}$ \\
\hline $\begin{array}{l}\text { Laminarinase-Cellobiase } \\
\text { Laminarinase-Maltase } \\
\text { Cellobiase-Maltase } \\
\text { n }\end{array}$ & $\begin{array}{l}+0.57 \cdots \\
+0.69 \cdots \\
+0.69 \cdots \\
10\end{array}$ & $\begin{array}{l}+0.68 \cdots \\
+0.64 \cdots \\
+0.42 \\
12\end{array}$ & $\begin{array}{l}+0.56 \\
+0.46 \\
+0.46 \\
10\end{array}$ & $\begin{array}{l}+0.34 \\
+0.50 \\
+0.60 \cdots \\
12\end{array}$ \\
\hline $\begin{array}{l}I_{\max } \text {-Dry weight } \\
F_{\text {midx }} \text {-Dry weight } \\
n\end{array}$ & $\begin{array}{l}- \\
- \\
-\end{array}$ & $\begin{array}{l}+0.54 \\
-0.43 \\
6\end{array}$ & $\begin{array}{l}+0.20 \\
-0.60 \\
5\end{array}$ & $\begin{array}{l}-0.30 \\
+0.49 \\
6\end{array}$ \\
\hline
\end{tabular}



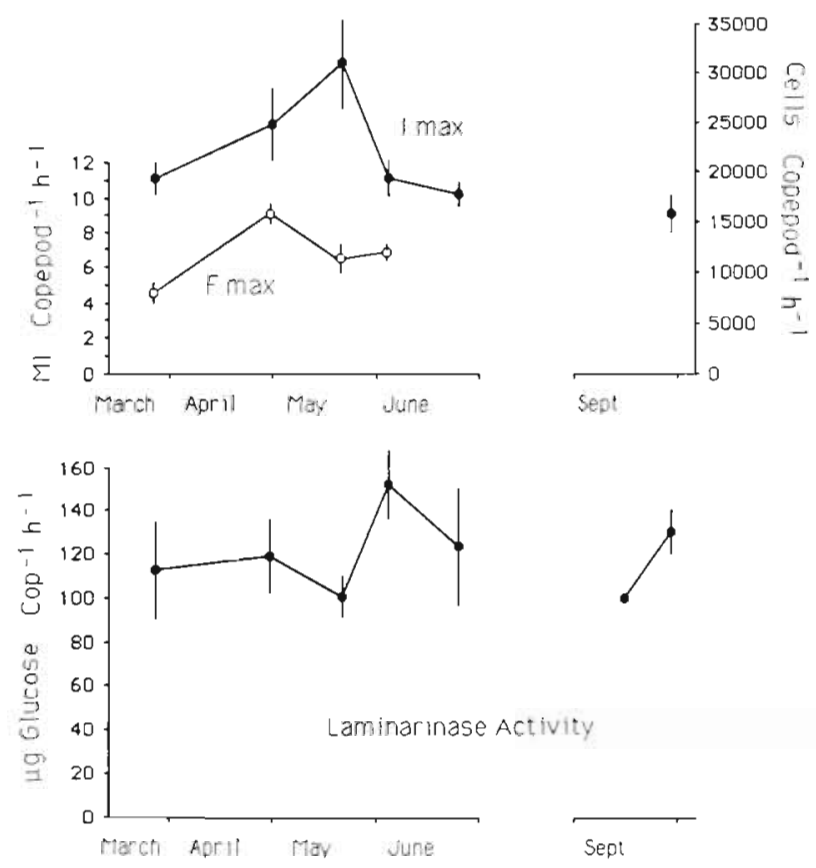

Fig. 4. Calanus pacificus. Seasonal changes in maximum ingestion rate $\left(\mathrm{I}_{\max }\right)$, maximum clearance rate $\left(\mathrm{F}_{\max }\right)$, and laminarinase activity in the main basin of Puget Sound, during spring and autumn 1984. Vertical lines denote $95 \%$ confidence intervals

observed by Landry et al. (1984) for C. pacificus feeding on the same diatom used here. A significant difference was observed on only one occasion (also on May 21, at low food concentrations; $\mathrm{p}<0.05$, Wilcoxon 2 -sample test), which was also the date when a food concentration effect was observed. While nitrogen AE did tend to be higher in these experiments, the differences were generally obscured by variability in the data. Also, on one date, April 30, assimilation efficiencies were determined for male C. pacificus feeding at high food concentrations. Assimilation efficiencies for males were $31 \pm$ 14 for carbon and $54 \pm 17$ for nitrogen (average and $95 \%$ confidence interval, $\mathrm{n}=6$ ).

\section{DISCUSSION}

The dominant feature of the seasonal feeding response of Calanus pacificus in Puget Sound is the increase in feeding rates and digestive enzyme activities in early spring. The observation of low enzyme activities during copepod diapause is well established (Hallberg \& Hirche 1980, Hirche 1981, 1983, Tande \& Slagstad 1982, Head \& Conover 1983). In addition, Hallberg \& Hirche (1980) noted degenerate gut epithelial cells in diapausing copepods. The results of Head \& Conover (1983) suggest that the development of the post-diapause copepod gut requires from 1

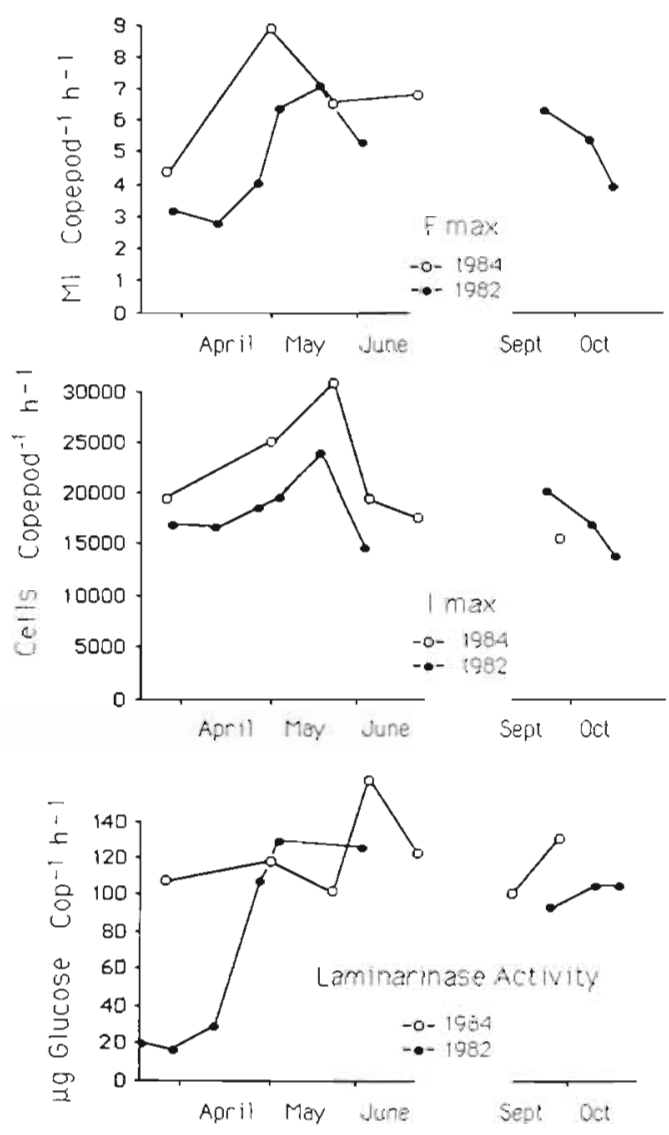

Fig. 5. Calanus pacificus. Comparison of seasonal trends in maximum clearance rate $\left(\mathrm{F}_{\mathrm{max}}\right)$, maximum ingestion rate $\left(\mathbf{l}_{\mathrm{max}}\right)$, and laminarinase activity in Puget Sound during 1982 and 1984

to $3 \mathrm{wk}$ and is a function of both temperature and the presence of food. Even starved copepods showed induction of enzyme activity as the copepodites developed and molted to adults although the presence of food both accelerated and enhanced the process. The field study reported here supports these earlier studies and clearly shows an increase in the feeding abilities of the copepods associated with the induction of enzyme activity. From the 1984 data there appears to be a wide latitude in the timing of the increase. This result is consistent with Head \& Conover's (1983) observation that the presence of food can speed enzyme induction.

While maximum, hunger-induced feeding rates and digestive enzyme activities develop concurrently at the start of the bloom, they do not appear to be coupled later in the season. Digestive enzyme activities remained high during periods in the late spring and early fall when maximum feeding rates were declining. Also, on a given day digestive enzyme activities were not correlated with feeding rates. It is not clear how the initial increases in feeding rates that we observed relate to Runge's (1980) study. Runge did not cover the 


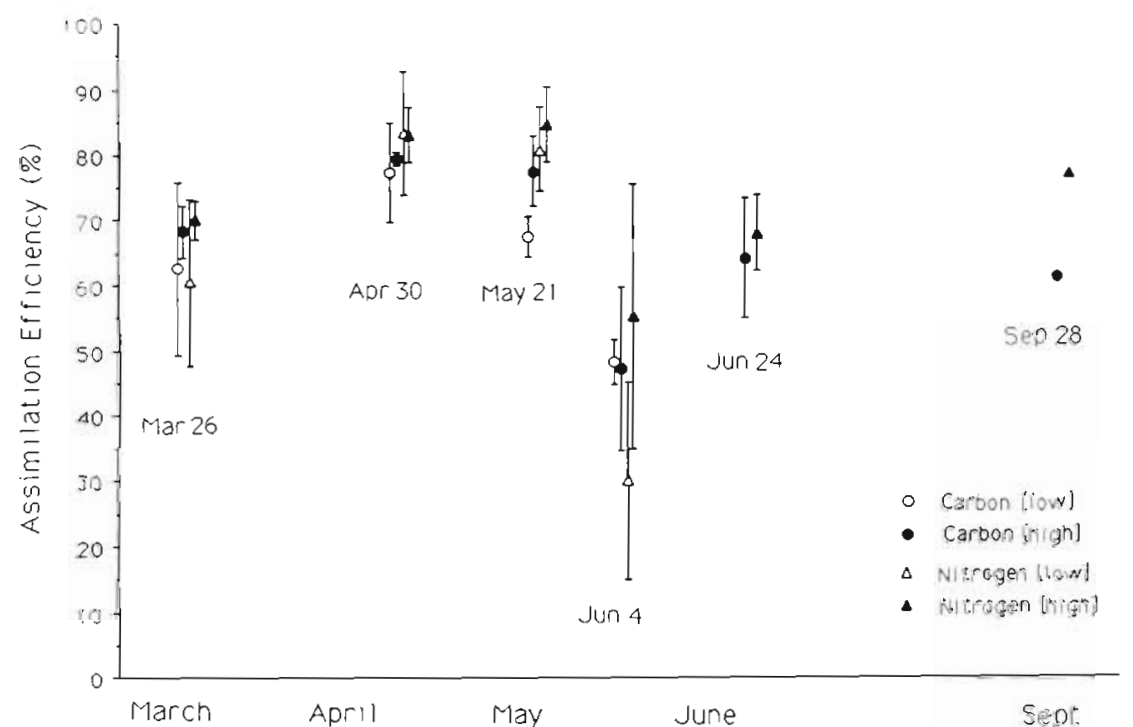

Fig. 6. Calanus pacificus. Seasonal changes in carbon and nitrogen assimilation efficiencies in the main basin of Puget Sound during 1984. Assimilation efficiencies were determined at low $\left(1500\right.$ cells $\left.-\mathrm{ml}^{-1}\right)$ and high $(6000$ cells $\mathrm{ml}^{-1}$ ) food concentrations. Vertical lines denote \pm 1 standard deviation. Only one sample of fecal pellets was analyzed on $\operatorname{Sep} 28$ period prior to the spring bloom and we did not extend far into June, where Runge found a peak in rates. However, Runge (1980) reported maximum clearance rates of 5.8 to $6.7 \mathrm{ml}$ copepod ${ }^{-1} \mathrm{~h}^{-1}$ for his June feeding experiments with Thalassiosira weissflogii (previously fluviatilis) and rates of 2.3 to 4.5 for his August and September experiments. Our estimates of clearance rate follow a similar seasonal pattern with the exception that our peak rates, in excess of $6 \mathrm{ml} \mathrm{copepod}^{-1}$ $\mathrm{h}^{-1}$, were observed as early as late April and mid-May, respectively, in 1984 and 1982. This would suggest that there might be considerable interannual variability in the seasonal patterns described by Runge (1980).

It is possible that absolute differences in feeding rates from year to year were due to differences in the Thalassiosira weissflogii culture (if the stock had

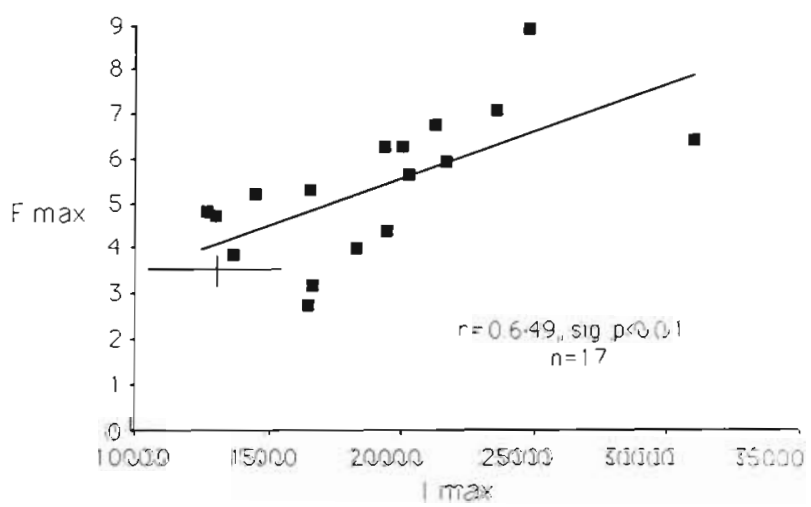

Fig. 7. Calanus pacificus. Maximum clearance rates ( $\mathrm{F}_{\max }, \mathrm{ml}$ copepod ${ }^{-1} \mathrm{~h}^{-1}$ ) versus maximum ingestion rates ( $I_{\max }$, cells copepod $\left.{ }^{-1} \mathrm{~h}^{-1}\right)$, measured in 1982 and 1984 feeding experiments. Data points are experimental mean estimates of poststarvation feeding rates sloped line is least-square linear regression fit to the data. Crossed lines represent $95 \%$ confidence intervals of $F_{\max }$ and $I_{\max }$ measured on continuously feeding copepods undergone changes in size, for instance) or to the shorter duration of feeding experiments in 1984 (3 to $4 \mathrm{~h}$ in 1984 vs 5 to $6 \mathrm{~h}$ in 1982). There may also have been significant differences in the phytoplankton cycle between 1982 and 1984. Dabob Bay, a nearby fjord, had an unusually early spring bloom in 1984, with Calanus pacificus coming out of diapause much earlier than normal (J. Downs pers. comm.). Although spring blooms in Dabob Bay are initiated by different physical conditions than blooms in the main basin of Puget Sound, it is possible that both areas were anomalous in 1984, and that the high laminarinase activity in late March was due to an early spring bloom. Head \& Conover (1983) have shown that induction of enzyme activity in Calanus hyperboreus occurred as they come out of diapause regardless of whether food is present. However, induction occurred faster and to a greater extent in the presence of food. An early bloom could thus have brought about an early induction of enzyme activity in C. pacificus in the spring of 1984.

One point that should be made is that the feeding rates measured prior to the bloom are only low relative to rates measured later in the spring. The lowest hunger-induced feeding rates of the present study, which includes the pre-bloom rates (Mar 29 and Apr 12, 1982), are comparable to rates observed for continuously feeding Calanus pacificus (Fig. 7; data for continuously feeding copepods from Hassett \& Landry 1983). At constant, high food concentrations, C. pacificus feeds at the same rate that it does prior to the spring bloom, when its digestive system is poorly developed. These 2 conditions may be related if the ability of the gut cells to regenerate is limited when feeding continuously at high food concentrations (see Nott et al. 1985), just as the gut is limited by lack of development in early spring. The hunger-induced response, the ability to ingest at higher rates for short 
periods of time, may thus be a behavior that is limited by the assimilation of food in the gut.

Since the digestive system of the copepods had apparently been fully developed at the start of the 1984 field season, it is not clear that assimilation efficiency would have shown the same trend as feeding rates and enzyme activities in early 1982, that is, initial low values followed by a sharp increase. However, there is evidence to support such a relationship. Although the laminarinase levels appear to have been fully developed at the start of the 1984 study, the trend in feeding rates were similar in the 2 years (Fig. 5). Given the rapid increase in enzyme activity observed in 1982 , it is possible that the 1984 study was begun just as the enzyme activities were peaking. Assimilation efficiencies were lower, particularly for nitrogen, on that first sampling date in 1984, consistent with an increase during the early spring. Also, male Calanus pacificus have lower enzyme activities and feeding rates than females in late spring (Hassett 1986), and males of $C$. finmarchicus and $C$. helgolandicus demonstrate both low enzyme activities and reduced digestive epithelial cells relative to females (Hallberg \& Hirche 1980). Thus, the male gut may be analogous to the underdeveloped gut of the early-spring female. In one experiment conducted with males in this study, they had much lower assimilation efficiencies than did females on the same date. In general, the data are consistent with the view that assimilation efficiencies, like digestive enzyme activities, rapidly peak in early spring and remain high throughout the feeding season, despite high week to week variability in phytoplankton availability estimated from chlorophyll a (Fig. 1).

Sampling was not conducted during summer in this study, so that it is unknown how much variation in enzyme activity occurred during this period. Activities for laminarinase were comparable in spring and fall both in 1982 and 1984, suggesting that high activities will be maintained once induced. However, much seasonal variability in activity, beyond an initial induction period, has been observed in other species of Calanus (Hirche 1981, Tande \& Slagstad 1982) and in community averages (Mayzaud \& Conover 1976).

In contrast to laminarinase, cellobiase varied markedly between spring and fall in 1982, although the reason for this difference is unclear. Both cellobiase and maltase showed strong seasonal signals in the zooplankton community in Bedford Basin (Mayzaud \& Conover, 1976), which is one reason why they were included in the present study. Cellobiase (B-glucosidase) is involved in the secondary digestion of laminarin (Avigad 1982, McConville et al. 1986) and so would be expected to be associated with laminarinase activity. The enzyme could also be involved in the secondary digestion of cellulose. We have detected cellulase activ- ity in Calanus pacificus, but the activity was extremely low, and so possibly the result of activity of an enzyme not specific for cellulose. In longterm acclimation experiments with C. pacificus, the highest cellobiase activities were induced when the copepod was fed the dinoflagellate Gymnodinium simplex (Hassett 1986). Why cellobiase would increase in response to $G$. simplex is a puzzle, as dinoflagellates utilize starch (which is hydrolyzed by amylase and maltase) as a storage product. although cellulose would be present in the cell wall material (Bold \& Wynne 1978). While phytoplankton species distributions were not determined in the field studies reported here, inspection of net samples for 1979 and 1980 revealed that dinoflagellates were abundant (particularly Peridinium and Ceratium spp.) in several of the late summer and fall samples. Also, a survey of phytoplankton species distribution by Anderson et al. (1984) for the Municipality of Metropolitan Seattle (Metro), which partly overlapped our seasonal study, indicates that dinoflagellates are important numerically, relative to diatoms, during late summer and fall while being swamped by diatom numbers during the spring bloom. Thus the cellobiase increase observed in the field study may be a response to a seasonal shift in food supply to dinoflagellates. A similar response was proposed by Hirche (1981), who suggested that a shift in the proportions of amylase and trypsin activity in field samples of $C$. finmarchicus and $C$. helgolandicus may also have been due to a shift in phytoplankton dominance from diatoms to dinoflagellates.

Enzyme induction in copepods recovering from diapause appears to be largely nonspecific (Head \& Conover 1983), most likely related to the development of gut epithelial cells as indicated by Hallberg \& Hirche (1980). From this study it also appears that enzyme induction and feeding capabilities develop concurrently. Once digestive enzymes are induced, however, they become less closely coupled with feeding rates. An important consideration for this population of Calanus pacificus is the frequency of blooms from spring to fall. If digestive enzymes respond to dietary changes on a time scale of a day to a week, as suggested by several studies (Mayzaud \& Poulet 1978, Cox 1981, Hassett \& Landry 1983), then the frequent blooms observed in Puget Sound may dampen seasonal fluctuations in digestive enzyme activity. Changes in diet that persist over several bloom cycles in Puget Sound, such as that resulting from the fall transition to a dinoflagellate/diatom assemblage, may allow longer-term acclimation of digestive enzymes to occur.

Acknowledgements. We gratefully acknowledge the assistance of $\mathrm{V}$ Fagerness and J. Lehner-Fournier with the field collections. Our work was supported by Department of Energy Contract DE-AT06-76-EV-75026 and Grant DE-FG0588ER60628. 


\section{LITERATURE CITED}

Anderson, J., Copping, A, Jagielo, T., Postel, J., Peterson, W. Dumbauld, B., Heron, G., Hood, R., Strom, M. (1984). Renton sewage treatment plant project: Seahurst baseline study. Vol. III, Section 4. Water column ecology. Univ. of Washington, Fisheries Research Institute Document FRIUW-8413

Avigad, G. (1982). Sucrose and other disaccharides. In: Loewus, F.. Tanner, W (ed.) In: Encyclopedia of plant physiology. Vol. 13A. Plant carbohydrates. 1 Intracellular carbohydrates. Springer-Verlag, Berlın, p. 217-347

Bold, H. C., Wynne, M. J. (1978). Introduction to the algae. Structure and reproduction. Prentice Hall, Inc., Englewood Cliffs, New Jersey

Collias, E. E., McGary, N., Barnes, C. A. (1974). Atlas of physical and chemical properties of Puget Sound and its approaches. Univ. of Washington, Seattle

Cox, J. L. (1981). Laminarinase induction in marine zooplankton and its variability in zooplankton samples. J. Plankton Res. 3: 345-356

Frost, B. W (1972). Effects of size and concentration of food particles on the feeding behavior of the marine planktonic copepod Calanus pacificus. Limnol. Oceanogr 17: 805-815

Hallberg, E., Hirche, H.-J. (1980). Differentiation of the midgut in adults and overwintering copepodids of Calanus finmarchicus (Gunnerus) and C. helgolandicus Claus. J. exp. mar. Biol. Ecol. 48: 283-295

Hassett, R. P. (1986). The effect of feeding history on the feeding behavior of Calanus pacificus. Ph. D. thesis, University of Washington

Hassett, R. P., Landry, M. R. (1982). Digestive carbohydrase activities in individual marine copepods. Mar. Biol. Lett. 3: $211-221$

Hassett, R. P., Landry, M. R. (1983). Effects of food-level acclimation on digestive enzyme activities and feeding behavior of Calanus pacificus. Mar. Biol. 75: 47-55

Hassett, R. P., Landry, M. R. (1988). Short-term changes in feeding and digestion by the copepod Calanus pacificus. Mar Biol. 99: 63-74

Head, E. J. H., Conover, R. J. (1983). Induction of digestive enzymes Calanus hyperboreus. Mar. Biol. Lett. 4: 219-231

This article was submitted to the editor
Hirche, H.-J. (1981). Digestive enzymes of copepodids and adults of Calanus finmarchicus and C. helgolandicus in relation to particulate matter. Kieler Meeresforsch., Sonderh. 5: 174-185

Hirche, H.-J. (1983). Overwintering of Calanus finmarchicus and C. helgolandicus. Mar. Ecol. Prog. Ser. 11: 281-290

Landry, M. R., Hassett. R. P., Fagerness, V., Downs, J., Lorenzen. C. J. (1984). Effect of food acclimation on assimilation efficiency of Calanus pacificus. Limnol. Oceanogr. 29 . 361-364

Landry, M. R., Hassett. R. P. (1985). Times scales in behavioral, biochemical, and energetic adaptations to food-limiting conditions by a marine copepod. Arch. Hydrobiol. Beih. Ergeb. Limnol. 21. 209-221

Lorenzen, C. J. (1966). A method for the continuous measurement of in vivo chlorophyll concentration. Deep Sea Res. 13: $223-227$

Mayzaud, P., Conover, R. J. (1976). Influence of potential food supply on the activity of digestive enzymes of neritic zooplankton. In: Persoone, G., Jaspers, E. (eds.) Proc. 10th Eur. Symp. Mar. Biol., Vol. 2. Universa Press, Wetteren, p. $415-427$

Mayzaud, P., Poulet, S. A. (1978). The importance of the time factor in the response of zooplankton to varying concentrations of naturally occurring particulate matter. Limnol. Oceanogr 23: 1144-1154

McConville, M. J., Ikeda, T., Bacic, A., Clarke, A. E. (1986) Digestive carbohydrases from the hepatopancreas of two euphausiid species (Euphausia superba and E. crystallorophias). Mar. Biol. 90: 371-378

Nott, J. A., Corner, E. D. S., Mavin, L. J., O'Hara, S. C. M. (1985). Cyclical contributions of the digestive epithelium to faecal pellet formation by the copepod Calanus helgolandicus. Mar. Biol. 89: 271-279

Runge, J. A. (1980). Effects of hunger and season on the feeding behavior of Calanus pacificus. Limnol. Oceanogr. 25: $134-145$

Tande, K. S., Slagstad, D. (1982). Ecological investigation on the zooplankton community of Balsfjorden, northern Norway. Seasonal and short-time variations in enzyme activity in copepodite stage $V$ and $V I$ males and females of Calanus finmarchicus (Gunnerus). Sarsia 67: 63-68

Manuscript first received: September 7, 1989

Revised version accepted: January 25, 1990 